\title{
How Can We Help You?
}

\section{An Exploration of What Institutional Websites Reveal About First-generation Support Services}

\author{
Lynell Hodge ${ }^{1}$, Amanda Wilkerson ${ }^{2}$, and Emmanuela Pierre Stanislaus ${ }^{3}$ \\ ${ }^{1}$ Housing \& Residence Life, University of Central Florida, ${ }^{2}$ College of Community Innovation and Education, \\ University of Central Florida, and ${ }^{3}$ Career and Talent Development-College of Engineering \& Computing, Florida \\ International University
}

Cite as: Hodge, L., Wilkerson, A. \& Stanislaus, E.P. (2020). How Can We Help You?: An Exploration of What Instutitional Websites Reveal About First-generation Support Services. Metropolitan Universities, 31(1), 92-112. DOI: $10.18060 / 23360$

This is an open access article distributed under the terms of the Creative Commons Attribution License.

Editor: Valerie L. Holton, Ph.D.

\begin{abstract}
Institutional websites are powerful tools that communicate wide range of information. Providing access to higher education requires institutions to consider how services are communicated with a goal of engaging students from diverse populations. This study utilized a conceptual content analysis to review university and college websites to determine how information about support services for first-generation students is electronically communicated. The researchers constructed an evaluative study to assess 14 institutions to formulate a critique and extend the work of Eccles's expectancy-value theory (1984), which suggests that achievement-related choices are motivated by students' expectations for success. The results of this study found salient factors to indicate that institutions sought to provide support for first-generation students, but relevant information was not always explicitly conveyed on websites, particularly in ways most likely to engage diverse populations.
\end{abstract}

Keywords: first-generation, college students, expectancy-value theory, content analysis, rubric 


\section{Introduction}

Substantial research is dedicated to understanding first-generation college students with regard to inclusion, transitional experiences, and academic achievement (Pike \& Kuh, 2005; Tinto, 2012; Toutkoushian, Stollberg, \& Slaton, 2018). As a result, researchers have provided a perspective on descriptions of first-generation college students (Saenz, Hurtado, Barrera, Wolf, \& Yeung, 2007), their rate of college completion (Greenwald, 2012), and barriers that might inhibit firstgeneration students’ progress toward degree completion (Stephens, Fryberg, Markus, Johnson, \& Covarrubias, 2012). These key areas of knowledge situate how post-secondary institutions describe axioms of support that are congruent with services provided to first-generation college students (Petty, 2004).

Many studies suggest that first-generation college students are more likely than their counterparts to leave college without a degree (Engle, Bermeo, \& O'Brien, 2006; Engel \& Tinto, 2008; Mehta, Newbold, \& O'Rourke, 201). Similarly, literature has shown the difficulty of defining characteristics which encompass a concrete description of first-generation students (Chen, 2005; Redford, \& Hoyer, 2017; Warburton, Bugarin, \& Nunez, 2001). What is consistent though, is that the term first-generation student often refers to learners whose parents lack some form of college credentials (Cataldi, Bennett, \& Chen, 2018). Furthermore, scholarship regarding firstgeneration students robustly accounts for services which fortify college completion to include: scaled multidimensional academic, emotional, and financial support (Dennis, Phinney, \& Chuateco, 2005; Jenkins, Belanger, Connally, Boals, \& Durón, 2013; Lohfink \& Paulsen; 2005). Moreover, data presented by the National Center for Education Statistics (Cataldi, Bennett, \& Chen, 2018) confirmed that first-generation college students account for nearly one-third of students enrolled in U.S. post-secondary institutions. Given the necessity of supporting firstgeneration students, other areas of research are devoted to understanding the characteristics and needs of this student population. Alongside the existing body of empirical works, research on first-generation students has expanded to also include how collegiate programmatic interventions might assist in progressing through degree completion (Engle, Bermeo, \& O'Brien 2006; Ishitani, 2006; Terenzini, Springer, Yaeger, Pascarella, \& Nora, 1996). Over time, researchers have identified barriers that contribute to conditions that inhibit student success. Among those barriers are socioeconomic status, academic preparedness, and/or campus engagement (Allen, Muragishi, Smith, Thoman, \& Brown, 2015; Stebleton \& Soria, 2013). However, the literature has not identified how to disseminate information regarding available support services to first-generation students. Relatedly, Gordon and Berhow suggested that post-secondary websites have the capacity to build dialogic exchanges with student users (2009). Moreover, our research on the needs of first-generation students makes clear that it is important to identify and articulate both what services are needed and how students can independently locate these services through an institution's website. The National College Access Network Report indicates the existence of shrinking options for low-income students nationwide due to growing disparities in college cost 
versus student affordability (2019). However, legislative reform efforts through the Higher Education Act (2017), and the Aim Higher Act (2018) have leveraged additional resources to support low-income, first-generation students. The existence of programs designed to ease the financial burden of low-income students makes critical the work of those conducting firstgeneration student research; first, they must begin to critically frame the premise of firstgeneration student support beyond merely identifying such students and itemizing their needs. Next, they must account for how to disseminate information about said services.

The United States Department of Education produced a study which clarified the critical issues regarding first-generation college students. In the report, First-Generation Students (2018), data about college access, persistency, and post-bachelor's outcomes indicated that first-generation undergraduate students were less likely to earn a credential in comparison to their counterparts whose parents did attend college (Cataldi, Bennett, \& Chen, 2018). Another revealing conclusion was that first-generation data focused on describing the student and providing typologies of student success based on data correlating parental background information with college completion trends. Nevertheless, there remains a void in academic literature specifically focused on the trajectory and/or active academic support as it pertains to institutional practices regarding leveraging online spaces to connect first-generation students with information for support services (Wilson, 2004).

For instance, Pascarella, Pierson, Wolniak, and Terenzini’s (2004) discussions on firstgeneration students omits an acknowledgement of how students can locate information about services, instead referencing only what services are needed to successfully progress to and through the college experience. In contrast, embedded into the available body of knowledge is research that focuses on utilizing the internet to counsel students, predict student success, and/or use technology to survey student experiences in the first year (Chang, T. \& Chang, R; 2004; Kennedy, Judd, Churchward, Gray, \& Krause, 2008). In other words, the shared seminal work suggests that first-generation students are an important topic of study. Interestingly, this argument serves as a starting point for investigating first-generation college students more broadly.

The research team intended to extend the work of previous studies by conducting an examination of universities, to include major metropolitan urban universities, to understand the needs of this population and how to provide pathways for these students to electronically locate helpful academic information. One way to achieve the goal of identifying methods to share information about available support services with first-generation college students is to thoroughly examine information currently provided by colleges and universities. To this end, the research team explored urban metropolitan institutions and examined the extent to which they share support services online with first-generation students seeking information about undergraduate degree offerings. Thus, the purpose of this study was to investigate how colleges and universities 
aggregate and/or organize academic and nonacademic support for first-generation college students. The research questions for this study were as follows: How does the southeastern region of the Coalition of Urban and Metropolitan Universities (CUMU) communicate information about first-generation student services on institutional websites? What pathways exist to locate information about first-generation student services on institutional websites?

The significance of this study is twofold. First, there continues to be groundbreaking empirical data on first-generation students, their needs, and ways in which universities aid and support their success. Second, first-generation scholarship is very much rooted in the academic trajectories of undergraduate post-secondary students. Specifically, first-generation students often study at large metropolitan urban institutions (McGregor, Mayleben, Buzzanga, \& Davis, 1991). At the same time, the ways in which institutions provide service information for firstgeneration students online are rarely evaluated. An examination of the existing information on institutional websites will aid in the development of more effective practices associated with supporting first-generation students with information about how they might independently utilize school-based resources to succeed. Moreover, this work deconstructed digital discourse as it relates to improve the academy for learners (Devine \& Levin, 2013).

\section{Literature Review}

College websites are one tool that students use at a high rate to gather information. According to the National Association for College Admission Counseling (2018), email and websites are the primary sources of information for first-time freshmen students. Of particular importance is how content is organized and the ease of navigation, which also includes the number of clicks students must take to reach the content they seek (Meyers, 2008). Poock \& LeFond (2001) illuminated the elements that are barriers for prospective students, including inefficient search functions, not locating desired information, and too many clicks to reach desired information. Given the importance of websites to first year students, it is imperative to analyze how higher education institutions use their websites to communicate resources that would be critical to the success of first-generation students.

\section{First-Generation Students}

The U.S. Department of Education defined first-generation students as students whose parents have achieved a high school diploma or less (Nunez \& Cuccaro-Alamin, 1998). Institutions have adopted varying definitions, to include some college education without receiving a degree, and even encompassing parents who have received a college degree outside of the U.S. (Whitley et al., 2018). Traditionally, federally-funded programs such as TRIO, Student Support Services, and Ronald E. McNair Post-Baccalaureate Achievement Program have provided much needed support to first-generation and low-income students (Engle \& Tinto, 2008). The importance of 
identifying first-generation students lies in institutions' ability to efficiently monitor and support their academic success (Center for First-Generation Student Success, 2017).

First-generation students tend to attend higher education institutions that are located close to home and are typically 2-year and 4-year public institutions. The decision to attend these institutions is due in large part to familial financial contribution, parent motivation, student career goals, and academic preparedness (Cabrera \& La Nasa, 2000).. Consequently, the factors that influence first-generation students' college choice is the thesis for this study. CUMU is one of the largest organizations of urban metropolitan institutions. The organization was created in 1989 to bring similar organizations together to discuss issues and trends that aligned with the unique mission, challenges, and student make-up of these specific institutions. The CUMU is currently made up of over 100 institutions throughout the U.S. as well as international institutions which enroll over two million students.

Research focused on first-generation students has pointed to several areas to support this group, including college readiness and low self-esteem, financial stability, peer-to-peer support, sense of belonging, and enrollment status (Strayhorn, 2008; Garriott \& Nisle, 2018; Tym, McMillion, Barone, \& Webster, 2004). These factors are central to the current study's analysis and recommendations and will be discussed in the subsequent sections.

\section{College Readiness/Low Academic Self Esteem}

Existing research on first-generation students indicates that this population is typically comprised of students of color from under-resourced K-12 schools (Portnoi \& Kwong, 2019; Pascarella et al., 2004). Students from under-resourced schools tend to struggle academically in college, which can lead them to question their pursuit of a college education. Imposter syndrome is related to self-esteem and can lead to poor performance and even attrition; this phenomenon involves self-doubt in abilities in comparison to the majority (Gardner \& Holley, 2011). Lack of confidence impacts how first-generation students approach challenges (Ward et al., 2012).

\section{Financial Stability}

First-generation students seek higher education for the prospects of better employment opportunities. However, insufficient financial resources result in first-generation students taking reduced course loads, seeking more student loans, or discontinuing their attendance altogether (Cataldi, Bennett, \& Chen, 2018). Financial instability also leads to the increased need for students to work. Increased work has shown to negatively impact student involvement in academic pursuits (Engle \& Tinto, 2008). Family assets are directly linked to financial resources available to support pursuit of a college degree. First-generation students are typically not able to depend on their parents for financial support; therefore, limited access to finances has led first- 
generation students to take on more debt than they are comfortable with (Gardner \& Holley, 2011). One recent study revealed that college students graduated with an average of $\$ 37,172$ worth of debt (Friedman, 2018).

Peer-to-Peer Support and Sense of Belonging

First-generation undergraduate students work more hours, are less likely to reside on-campus, have less involvement in extracurricular activities, and experience less peer interaction outside of academic environments (Pascarella et al., 2004). Pascarella et al. (2004) found that involvement positively impacted critical thinking and overall success of those who were engaged. They also found that interactions with peers outside of the classroom helped to grow students' social capital. Both involvement and peer interactions tended to have a greater impact for firstgeneration students' success compared to that of non-first-generation students. Furthermore, peer support has shown to provide vital assistance to first-generation undergraduate students even more so than family support (Dennis, Phinney, Chuateco, 2005; Strayhorn, 2008). Related to peer-to-peer support is the concept of sense of belonging. Specifically, first-generation students experience feelings of not belonging on college campuses (Stebleton, Soria, \& Huesman, 2011). Garriott and Nisle (2018) state that low sense of belonging impacts first-generation students’ ability to locate such resources as counseling, mentorship, and tutoring that can assist them in coping with challenges associated with being the first in their family to attend college.

\section{Enrollment Status/Attrition}

Enrollment status has shown to impact the academic success of first-generation students; students who enroll part-time (fewer than 12 credits) tend to take longer to graduate (Pascarella et al., 2004). First-generation undergraduate students are more likely than non-first-generation to enroll on a part-time basis (Ward et al., 2012). Enrollment status and attrition were negatively impacted by delayed enrollment, part-time enrollment, full-time employment, financial dependence, and dependent children (Seay et al., 2008). These risks are known to some degree, yet whether and how institutions of higher education support first-generation students in these areas and how they communicate their support remains unknown.

\section{Expectancy-Value Theory}

The current study seeks to explore the communication of support services for first-generation college students at research institutions utilizing the Expectancy-Value Theory as a theoretical framework. The Expectancy-Value Theory is an adaptation of the Atkinson's Expectancy-Value model (Eccles \& Wigfield, 2002; Eccles, Adler, \& Meece, 1984). The modern expectancyvaluetheory is typically used with adolescents to assess gender differences in choosing STEM programs. Eccles’ modification accounts for both the positive and negative experiences that can 
impact the choices students make as determined by the expectancy and values associated with a task. Expectancy is tied to the likelihood for success associated with choices as well as to beliefs related to competency. Additionally, expectancy is related to how students perceive others' perception of them and their abilities. Furthermore, the model elaborates that expectancies and values are related to performance, persistence, and task choice (Eccles \& Wigfield, 2002). This framework provides a unique lens to critique university websites and is a crucial element for the analysis of this study.

\section{Methods}

Content analysis is a systematic qualitative research procedure that is a dynamic methodology allowing researchers to corroborate at least two data sources; data sources can be either print or electronic (Yin, 1994). An effective analysis data must be examined to create meaning, develop understanding, and advance empirical knowledge (Corbin \& Strauss, 2008). Content analysis can be conducted on three types of documents: public records, which are official, ongoing records of an organization's activities; personal documents, the personal effects of an individual's actions, experiences, and beliefs; or physical evidence, the objects found within the study setting or artifacts (O'Leary, 2014). Researchers then code content into themes or categories that emerge from the literature and utilize a rubric to grade or score content they analyze (Bowen, 2009). Content analysis is particularly applicable to qualitative case studies generating rich explanations for a phenomenon, event, organization, or program (Stake, 1995). The use of rubrics in content analysis evaluation can increase transparency in research while decreasing subjectivity in the assessment process (Silvestri \& Oescher, 2006).

A rubric is a coherent set of criteria that includes descriptions of characteristic parameters for the criteria. An effective rubric can help organizations identify their strengths and weaknesses and objectively assess their services (Chowdhury, 2019). A rubric has three essential features: evaluation criteria, quality definitions, and a scoring strategy (Popham, 1997). Research indicates that rubrics can provide constructive feedback to enhance the learning and development process. Understanding the use of web-based communication, content, and tools is essential in the creation of websites that are indicative of organizational values and beliefs (Nacar \& Burnaz, 2011). Because websites enable organizations to create a new, standardized mode of communication whereby end-users can engage with electronic language, their function as a communication vehicle and knowledge organizer requires the institution to facilitate navigational ease of its website (Nantel \& Glaser, 2008).

\section{Study Design}

With the wealth of information available regarding support services for first-generation students, a rubric was developed to assess institutions in the southeast region of Coalition of Urban and 
Metropolitan Universities. It was important to select institutions with the propensity to admit and provide support services to first-generation students. The literature suggests that first-generation students tend to be students of color, come from low-income backgrounds, and seek postsecondary education in urban schools that provide access to college (Portnoi \& Kwong, 2019). To narrow the search for this study, the Coalition of Urban and Metropolitan Universities (CUMU) universities were selected to analyze data. CUMU is one of the largest organizations committed to serving and connecting urban and metropolitan universities. It focuses on strengthening institutions that are developing new responses to the contemporary educational, economic, and social issues. These institutions attract first-generation students due to their location, services, and, often, access to support. The 14 selected institutions are CUMU member institutions and were evaluated on the basis of the following criteria:

1. How does the southeastern region of the Coalition of Urban and Metropolitan Universities (CUMU) communicate information about first-generation services on institutional websites?

2. What pathways exist to locate first-generation services on institutional websites?

In addition to the above research questions, the research team utilized a rubric criterion, as shown in Table 1, to conduct a conceptual content analysis to assess university programs and services of first-generation students. This methodological approach was used to make the assessment process less arbitrary and to specify what data to include/exclude in the review in order to best address the research framework. The scoring provided a baseline to evaluate information listed on institutional websites.

Table 1. Website Rubric Criteria

\begin{tabular}{|l|l|l|}
\hline Model (3) & Developing (2) & Foundational (1) \\
\hline Demonstrates support for & Demonstrates support for & Demonstrates support for students, but \\
first-generation students and & first-generation, but vague & no specific language in reference to \\
clearly states how students & description of how & first-generation student services. \\
are identified to use and & students are identified to & \\
access service(s). & use and access service(s). & \\
\hline
\end{tabular}

The rubric categories were established with areas of first-generation student needs identified by the extensive body of research and by the values of the eccles expectancy-value theory. The research team developed this rubric in order to create a framework to specifically assess the needs of first-generation students as they relate to support services and/or resources available on institutional websites.

Considerations of reliability and validity depend on the ability of the researcher to explain the data and provide transparent reasoning about the findings as well as their limits. As such, while the rubric provides a standard measure for the review team, the rubric was not tested for validity 
or reliability. Additionally, this research study is grounded in a qualitative procedures; therefore, the results can be categorized as binominal (yes, this information was found, or no, this information was not found) of the selected CUMU institutional websites. The study sample consisted of the southeastern region of the CUMU; these institutions represent seven states in the southeastern United States (Arkansas, Florida, Kentucky, North Carolina, Louisiana, Tennessee, and Virginia) with diverse student populations.

\section{Data Collection}

To effectively collect and assess the data, the research team conducted a "first-generation" word search on institutional websites. Data was collected from institutional Home, About, and Financial Aid sections. Hossler (1999) postulates prospective students are interested in searching for specific characteristics of a campus, such as programs/services offered and financial aid. Therefore, websites are critical tools for student research these selections were grounded in the assumption that first-generation students would naturally gravitate to familiar sections of institution websites.

Data collection occurred from May 2019 through July 2019. Collecting the information during this time period, as it follows the spring academic term and precedes the start of the next academic year's fall term, was helpful because up-to-date and semi-static information about a college/university's new and existing programs should be, at that time, posted online, as should requirements for aid for the upcoming year. Each research team member was assigned to individually assess first-generation support services provided by specific institutions from CUMU's southeastern region list. The analysis was based on the institutional definition of firstgeneration and on services listed, if any. Each researcher utilized the constructed rubric for consistency and to ensure the measurements for convergent validity. This method of assessment allowed researchers to compare findings from the selected websites; this evaluator process allowed side-by-side comparison for deeper analysis and discussion.

\section{Coding and Intercoder Reliability}

In order to thoroughly review websites associated with the study, the researchers developed a coding schema utilized for analysis. Of the three researchers, each was assigned and submitted initial codes in accordance with the rubric parameters. Websites were reviewed based upon the following scales provided in the rubric. During individual scoring, members of the team utilized an Excel workbook with different spreadsheets to rate the sites. As a form of trustworthiness, site scores were sent to the study's first author who merged and compiled the scored data (DeCuitGunby, Marshall, \& McCulloch, 2011). During the compiling of the coded data, if a discrepancy emerged the researchers would review the material together and discuss the coding until a consensus was met. To assess percent agreement the research team drew upon the work of 
Lombard, Snyder-Duch, and Campanella Bracken (2006). Overall 14 websites were reviewed in five specific areas, as shown in Table 2 . The researchers' scores matched $90 \%$ of the time and remaining discrepancies were addressed through a consensus (Lombard et al, 2006).

\section{Results}

Because this study was exploratory, the analysis was largely binominal assessment (yes or no) via the rubric. The purpose of this study was to investigate how the selected institutions organize academic and nonacademic support for first-generation college students utilizing the eccles expectancy-value theory, as shown in Table 2.

The study examined pathways forged or communicated via the website to assist first-generation students, with the understanding that this population is expected to start at a disadvantage. Thus, while websites espoused the commitment to assisting first-generation students, relevant information was not always explicitly stated. One major test was to determine whether the institution defined what/who first-generation students are. This simple identifier of a definition provided a baseline for research; in the absence of this information, students may not be aware that they are in fact first-generation. In this case, three of the 14 schools failed to explicitly define first-generation. While this oversight occurred, the majority of the schools received points for their online verbiage, but on average institutions did not explicitly (written on page) discuss services for first-generation students; therefore, on average in the remaining categories received twos.

While the rubric provided an opportunity to assess institutional websites, the analysis indicated that websites may provide a touchpoint for access. However, some institutions relied on additional, non-digital, mechanisms to communicate such information, such as orientations or summer intensive programs. The institutions that did arrange information on their websites also shared demographic information about first-generation students, which provided an opportunity for first-generation students to relate to peers in order to cultivate an informal support system.

The common pathway institutions used was the About section or some iteration of the campus profile. First-generation students could navigate from this portion of the website to connect with or find first-generation resources. Another common pathway from this sample was the Financial Aid section. Of the institutional website sections analyzed by the researchers, Financial Aid often contributed to the assessment not only a definition of first-generation students, but also eligibility requirements for scholarships and other support services. This pathway resulted in a variation of clicks to access the desired information (i.e. no discernible pattern was identified). 


\begin{tabular}{|c|c|c|c|c|c|}
\hline Institution & Definition & $\begin{array}{l}\text { Attainment } \\
\text { (College } \\
\text { Readiness/ } \\
\text { Low Academic } \\
\text { Self-esteem) }\end{array}$ & $\begin{array}{l}\text { Intrinsic } \\
\text { (Peer-to- peer } \\
\text { support/ sense } \\
\text { of belonging) }\end{array}$ & $\begin{array}{l}\text { Utility } \\
\text { (Enrollment } \\
\text { Status) }\end{array}$ & $\begin{array}{l}\text { Cost (Financial } \\
\text { Stability) }\end{array}$ \\
\hline $\begin{array}{l}\text { Florida Atlantic } \\
\text { University }\end{array}$ & 3 & 3 & 3 & 3 & 3 \\
\hline $\begin{array}{l}\text { Florida International } \\
\text { University }\end{array}$ & 3 & 2 & 2 & 2 & 3 \\
\hline $\begin{array}{l}\text { Louisiana State } \\
\text { University-Shreveport }\end{array}$ & 1 & 1 & 1 & 1 & 1 \\
\hline Miami Dade College & 3 & 3 & 3 & 3 & 3 \\
\hline $\begin{array}{l}\text { University of Arkansas } \\
\text { at Little Rock }\end{array}$ & 3 & 2 & 1 & 1 & 2 \\
\hline $\begin{array}{l}\text { University of } \\
\text { Louisville }\end{array}$ & 3 & 3 & 3 & 3 & 3 \\
\hline University of Memphis & 1 & 2 & 2 & 3 & 2 \\
\hline $\begin{array}{l}\text { University of North } \\
\text { Carolina at Charlotte }\end{array}$ & 3 & 2 & 3 & 2 & 1 \\
\hline UNC at Greensboro & 3 & 3 & 2 & 2 & 2 \\
\hline UNC at Wilmington & 3 & 2 & 2 & 2 & 2 \\
\hline $\begin{array}{l}\text { University of North } \\
\text { Florida }\end{array}$ & 3 & 2 & 3 & 2 & 2 \\
\hline $\begin{array}{l}\text { University of } \\
\text { Tennessee at } \\
\text { Chattanooga }\end{array}$ & 3 & 2 & 3 & 2 & 1 \\
\hline $\begin{array}{l}\text { Virginia } \\
\text { Commonwealth } \\
\text { University }\end{array}$ & 3 & 3 & 3 & 3 & 2 \\
\hline $\begin{array}{l}\text { Virginia Wesleyan } \\
\text { University }\end{array}$ & 1 & 1 & 1 & 1 & 1 \\
\hline
\end{tabular}

Note: Combined results of research team website content analysis 
Additionally, the content analysis revealed that institutions that did not make information about first-generation student services readily available on the Home, About, or Financial Aid pages did, however, rely on TRIO. With this in mind it was helpful for the research team to see themselves as a first-generation student navigating university nomenclature ; higher education may learn that what is clear within the walls of the academe could be confusing for individuals who are unfamiliar to the environment; therefore, institutions should redirect to focus on the end user experience.

For instance, the research team were familiar with federally funded programs such as TRIO, but a first-generation student or family member may not. TRIO are outreach and student services programs designed to identify and provide services for students from disadvantaged backgrounds. TRIO programs are intended to assist low-income, first-generation college students, and students with disabilities to progress through the academic pipeline from middle school to post-baccalaureate programs. These programs are federally-funded and require institutions to officially request funding. These programs could also fall under Student Support Services' national funding.

During the analysis, the research team recognized a consistent pattern wherein institutions primarily focused on four areas of the rubric: attainment (college readiness/low academic selfesteem), intrinsic (peer-to-peer support/self of belonging), utility (enrollment status), and cost (financial aid), which further affirmed the rubric's validity. Websites provided several examples of tutoring and academic support via a full-time staff or a team trained specifically to respond to the needs of first-generation students. Similarly, institutions showcased peer support opportunities via several strategies, including mentoring, student organizations, and living learning communities. Institutions highlighted scholarships and grants specifically funded to assist first-generation students. Financial support, a listed vulnerability of this population, was the one area in the rubric most institutions highlighted, and which featured direct language to communicate information about services for first-generation students.

\section{Discussion}

To date, research often approached first-generation students through a deficit-model lens and focused on defining characteristics of first-generation students. Most research dealing with firstgeneration college students focused on their lack of capital and preparation necessary to succeed in higher education (Rubio et al., 2017). In contrast, this study assessed how 14 urban institutions of higher education communicate the support first-generation college students require to be successful. By using the expectancy-value theory, the research team utilized and offered a different strategy for assessing the experience of first-generation students.

(C) The Author 2020. Published by the Coalition of Urban and Metropolitan Universities. www.cumuonline.org 
Because many institutions identify first-generation students as a vulnerable population, it is important to effectively communicate to them about resources and services specific to their needs. The institutions in this study showed a great deal of commitment to the student experience and, in many cases, took pride in the services they provided. However, despite the demonstrated need that first-generation students and their families have for information about programs and services critical to their success, our analysis revealed that the information was not always readily present. Institution websites are an effective tool that can be used for students to conduct research, connect to offices/departments, and identify additional support that they need to be successful. Nonetheless, if institutions say they support first-generation students, their commitment to creating websites that clearly communicate resources is paramount.

Additionally, websites are fluid media; thus, they are regularly updated; and some of the content on institutional websites changed during the course of our data analysis. Using content analysis of institutional websites in this regard limits the generalizability of the research findings. While the research team performed an evaluable study the researchers would remind readers the results sought to answer a phenomenon utilizing a non-validated instrument for analysis. A content analysis for a website may be conducted but should be replicated with a validated tool.

\section{Practical Implications}

In this era of greater accountability, higher education is constantly responding to the changing educational landscape and to the changing needs of a diverse and dynamic student population. Limited resources and funding may prevent institutions from the ability to develop firstgeneration specific offices/departments. Notwithstanding the creation of separate services, tapping into the national Student Success Services pipeline may be a strategy to ensure that firstgeneration students are assisted. TRIO programs are specifically designated to assist this population, and, because this program is nationally established, it provides funding. The First Scholars Program represents another opportunity for institutions to support first-generation students via scholarships. Providing information about scholarship opportunities via websites supports first-generation student transition and retention.

Additionally, a specific focus on first-generation students highlights the many challenges they may experience. Taking into consideration the fact that these challenges suggest first-generation students are underprepared, this narrative is framed as a deficiency model. In the aggregate, however, first-generation students persist at the same rate or similar rates as non-first-generation students (Cataldi, Bennett, \& Chen, 2018). For this reason, institutions should consider reframing their approach and the information they provide in order to encompass these students' unique experience and promote this information via the websites. In as such, schools that considered including families in the orientation process or that provided specific information geared to helping students transition boasted higher retention and persistence rates. In this context, families 
should be considered an asset to supporting first-generation students through their college career and should be leveraged for the good of the student.

Another practical strategy institutions may consider is to conduct annual website reviews to ensure the existence of a seamless pathway to connect first-generation students to resources. Marketing research suggests the current consumer, in this case students, becomes more vested in their search when there are minimal clicks. Thus, first-generation students need to be able to easily and quickly find and access information. Some institutions in this study provided one a page specifically for first-generation students that linked to all relevant resources to; this page included videos and hyperlinks to other resources on campus. This approach allowed firstgeneration students to access information in a single location from which they could draw upon a wealth of resources. Such a landing page should take into consideration students' enrollment status, given that the needs of a prospective first-generation student will vary from those of a current student. For instance, prospective students may need information about the admissions process, while a current student may need such support services as tutoring and reapplying for scholarships. Regardless of the first-generation student's status, retention for this population may increase with efficient access to information about programs and services.

The last strategy is probably the simplest. The term "first-generation" is very much higher education nomenclature. Institutions must be keenly aware that students and families may not be aware they are a first-generation, or in some cases students may not have the language skills to include "first-generation" in their initial search. Schools in this study recognized there could be a language gap and provided a glossary of terms, which was one resource that was used to help families. This simple strategy could have a significant impact on the institution's effort to connect with the intended user.

\section{Future Research Directions}

This study's results indicate that there is more work to be done in the area of understanding firstgeneration information collection. The use of websites can indicate an initial strategy to communicate to first-generation students. Additionally, the opportunity to assess institutional pathways is critical. The research team makes the case that institutions should utilize their websites to connect with these students. As more such students enter higher education, the social capital in their network could help direct their search. Therefore, it is crucial for future researchers to consider where the possible touch points to provide information should be located. One consideration is to arm guidance counselors, clergy, and community centers with information about what services are specifically available to first-generation students. While the literature suggests that first-generation students currently rely on these support systems, more research should be conducted as how are these networks interact with institutional information in order to support first-generation students. 
Lastly, first-generations have been described both as underprepared and resilient. The unique experiences of first-generation students indicate this population may have emerging considerations that have yet to be explored. Researchers focusing on first-generation students should include them in the conversation. First-generation students are the experts of their experiences and could provide an enriched epistemology or specifically auto ethnographic narrative. This method of collecting experiences can be empowering; it can help researchers identify gaps and, more importantly, to assess the impact and intent. The use of first-generation students' narratives to ensure services are appropriate is encouraged, because engaging firstgeneration students in the process of identifying their needs demonstrates a commitment to supporting this population and also provides an opportunity for agency. As a result, the lens through which future generations view and assess the effectiveness of institutional websites and resource allocation would provide dynamic and informative narratives.

\section{Limitations}

While websites are dynamic tools of communication, the organization of each website was different, which required the research team to be creative in assessing information. For instance, websites may have listed first-generation resources in press releases or presidential state of the university remarks. Therefore, the pathway to extract first-generation was not always readily accessible or identifiable. To maintain consistency in the search, it was important for the research team to emulate search functions of first-generation students and take into consideration that students' search practices may be rudimentary. Lastly, while the primary focus of the study was to specifically identify resources via websites, our study did not take into consideration print resources, such as brochures, view books, or pamphlets. First-generation students and their families may not choose to search in this manner. Subsequently, budget reductions at many institutions necessitate cutting paper methods of communications and relying more heavily on websites. Nonetheless, websites can and should play a crucial role in connecting first-generation students to campus resources.

\section{Conclusion}

Many universities accept and enroll first-generation students, and they provide support through a variety of targeted and general services. However, whether first-generation students can efficiently access support services information within a few clicks on a given college or university's website is uncertain. As evidenced by this study, though schools have a wide range of available resources for first-generation students, locating this information sometimes proved to be difficult. Furthermore, identifying support services with the characteristics associated with expectancy value theory can effectively frame the type of information that might be beneficial 
for first-generation students. The desire to help first-generation students achieve academic success can provide the impetus for an institution's efforts to optimize first-generation support services communicated through its websites. As Engle and Tinto (2008) noted, first-generation students are likely to leave college after the first year; providing first-generation students with access to targeted information developed utilizing expectancy value theory might mitigate the impact of such a troubling notion. 


\section{References}

Allen, J. M., Muragishi, G. A., Smith, J. L., Thoman, D. B., \& Brown, E. R. (2015). To grab and to hold: Cultivating communal goals to overcome cultural and structural barriers in firstgeneration college students’ science interest. Translational issues in psychological science, 1(4), 331.

Aim Higher Act of 2018, U.S.C. §§ 6543

Astin, A. W. (1991). Assessment for excellence: The philosophy and practice of assessment and evaluation in higher education. New York: McMillan.

Bowen, G. A. (2009). Document analysis as a qualitative research method. Qualitative Research Journal, 9(2), 27-40.

Cabrera, A. F. \& La Nasa, S. M. (2000). Understanding the college-choice process. New Directions For Institutional Research, 107, 5-22.

Cadena, B. C. \& Keys, B. J. (2013). Can self-control explain avoiding free money? Evidence from interest-free student loans. The Review of Economics and Statistics, 95(4), 11171129.

Cataldi, E. F., Bennett, C. T., \& Chen, X. (2018). First-generation students: College access, persistence, and postbachelor's outcomes. Stats in Brief. NCES 2018-421. National Center for Education Statistics.

Center for First-Generation Student Success (2017, November 20). Defining first-generation. Retrieved from https://firstgen.naspa.org/blog/defining-first-generation

Chowdhury, F. (2019). Application of rubrics in the classroom: A vital tool for improvement in assessment, feedback and learning. International Education Studies, 12(1), 61-68.

Chang, T., \& Chang, R. (2004). Counseling and the internet: Asian American and Asian international college students' attitudes toward seeking online professional psychological help. Journal of College Counseling, 7(2), 140-149.

Chen, X. (2005). First-generation students in postsecondary education: A look at their college transcripts.

Corbin, J. \& Strauss, A. (2008). Basics of qualitative research: Techniques and procedures for developing grounded theory (3rd ed.). Thousand Oaks, CA: Sage.

Dean, D. R., \& Levine, A. (2013). Digital natives, digital immigrants, and the analog campus. HigherEdJobs.com.

(C) The Author 2020. Published by the Coalition of Urban and Metropolitan Universities. www.cumuonline.org 
DeCuir-Gunby, J. T., Marshall, P. L., \& McCulloch, A. W. (2011). Developing and using a codebook for the analysis of interview data: An example from a professional development research project. Field methods, 23(2), 136-155.

Dennis, J. M., Phinney, J. S., \& Chuateco, L. I. (2005). The role of motivation, parental support, and peer support in the Academic success of ethnic minority first-generation college students. Journal of College Student Development, 46(9)3, 223-236.

Dynarski, S. \& Scott-Clayton, J. (2013). Financial aid policy: Lessons from research. The Future of Children, 23(1), 67-91.

Eccles, J., Adler, T., \& Meece, J. L. (1984). Sex differences in achievement: A test of alternate theories. Journal of Personality and Social Psychology, 46(1), 26-43.

Eccles, J. S. \& Wigfield, A. (2002). Motivational beliefs, values, and goals. Annual Review of Psychology, 53, 109-132.

Engle, J., Bermeo, A. \& O'Brien, C. (2006). Straight from the Source: What works for firstgeneration college students. Pell Institute for the Study of Opportunity in Higher Education.

Engle, J. \& Tinto, V. (2008). Beyond access: College success for low-income, first-generation students. Washington, DC: Pell Institute.

Friedman, Z (2018). Student loan debt statistics in 2018: A \$1.5 trillion crisis. Retrieved from https://www.forbes.com/sites/zackfriedman/2018/06/13/student-loan-debt-statistics2018/\#5ca82fc87310

Fries-Britt, S. \& Griffin, K. (2007). The Black box: How high-achieving Blacks resist stereotypes about Black Americans. Journal of College Student Development, 48(5), 509524.

Gardner, S. K. \& Holley, K. A. (2011). Those invisible barriers are real: The progression of firstgeneration students through doctoral education. Equity \& Excellence in Education, 44(1), 77-92.

Garriott, P. O. \& Nisle, S. (2018). Stress, coping, and perceived academic goal progress in firstgeneration college students: The role of institutional supports. Journal of Diversity in Higher Education, 11(4), 436-450.

Greenwald, R. (2012). Think of first-generation students as pioneers, not problems. The Chronicle of Higher Education, 59, 12.

Gordon, J. \& Berhow, S. (2009). University websites and dialogic features for building relationships with potential students. Public Relations Review, 35(2), 150-152.

(C) The Author 2020. Published by the Coalition of Urban and Metropolitan Universities. www.cumuonline.org Metropolitan Universities | DOI 10.18060/23360 | February 21, 2020 
Higher Education Act of 1965, 20 U.S.C. §§ 1096 (2017)

Hossler, D. (1999). Using the internet in college admission: Strategic choices. Journal of College Admission, 162, 12-19.

Ishitani, T. T. (2006). Studying attrition and degree completion behavior among first-generation college students in the United States. The Journal of Higher Education, 77(5), 861-885.

Jenkins, S. R., Belanger, A., Connally, M. L., Boals, A., \& Durón, K. M. (2013). First-generation undergraduate students' social support, depression, and life satisfaction. Journal of College Counseling, 16(2), 129-142.

Kantrowitz, M. (2009). Growth in cumulative education debt at college graduation. Retrieved from www.finaid.org/educators/20090730cumulativedebt.pdf

Kennedy, G. E., Judd, T. S., Churchward, A., Gray, K., \& Krause, K. L. (2008). First year students' experiences with technology: Are they really digital natives?. Australasian journal of educational technology, 24(1).

Lohfink, M. M. \& Paulsen, M. B. (2005). Comparing the determinants of persistence for firstgeneration and continuing-generation students. Journal of College Student Development, 46(4), 409-428.

Lombard, M., Snyder-Duch, J., \& Bracken, C. C. (2002). Content analysis in mass communication: Assessment and reporting of intercoder reliability. Human communication research, 28(4), 587-604.

McGregor, Loretta N., Mechelle A. Mayleben, Victoria L. Buzzanga, and Stephen F. Davis. "Selected personality characteristics of first-generation college students." College Student Journal (1991).

Mehta, S. S., Newbold, J. J., \& O'Rourke, M. A. (2011). Why do first-generation students fail? College Student Journal, 45(1), 20-36.

Myers, K. A. (2008). The "virtual face" of institutions: What do home pages reveal about higher education? Innovation Higher Education, 33, 141-157.

Nacar, R. \& Burnaz, S. (2011). A cultural content analysis of multinational companies’ web sites. Qualitative Market Research: An International Journal, 14(3), 274-288.

Nantel, J. and Glaser, E. (2008). The impact of language and culture on perceived website usability. Journal of Engineering \& Technology Management, 25, 112-22. 
National Association for College Admission Counseling (2018). State of College Admission Report. Arlington, VA: National Association for College Admission Counseling.

National College Access Network. (2019). The growing gap: Public higher education's declining affordability for low income students. Washington, DC: Bill DeBaun, Carrie Warick.

Nunez, A. M. \& Cuccaro-Alamin, S. (1998). First-Generation students: Undergraduates whose parents never enrolled in postsecondary education (NCES 98-082). Retrieved from https://nces.ed.gov/pubs98/98082.pdf

O’Leary, Z. (2014). The essential guide to doing your research project (2nd ed.). Thousand Oaks, CA: SAGE Publications, Inc.

Pascarella, E. T., Pierson, C. T., Wolniak, G. C., \& Terenzini, P. T. (2004). First-generation college students: Additional evidence on college experiences and outcomes. The Journal of Higher Education, 75(3), 249-284.

Poock, M. C. \& LeFond, D. (2001). How college-bound prospects perceive university web sites: Findings, implications, and turning browsers into applicants. College and University, 77(1), 15-21.

Popham, W.J. 1997. What's wrong - and what's right - with rubrics. Educational Leadership, 55(2): 72-5.

Portnoi, L.M. \& Kwong, T.M. (2011). Enhancing the academic experiences of first-generation master’s students. Journal of Student Affairs Research and Practice, 48(4), 411-427.

Portnoi, L. M. \& Kwong, T. M. (2019). Employing resistance and resilience in pursuing K-12 schooling and higher education: Lived experiences of successful female first-generation students of color. Urban Education, 54(3), 430-458.

Redford, J. \& Hoyer, K. M. (2017). First-Generation and Continuing-Generation College Students: A Comparison of High School and Postsecondary Experiences. Stats in Brief. NCES 2018-009. National Center for Education Statistics.

Rubio, L., Mireles, C., Jones, Q., \& Mayse, M. (2017). Identifying issues surrounding firstgeneration students, American Journal of Undergraduate Research, 14(1), 5-10.

Terenzini, P. T., Springer, L., Yaeger, P. M., Pascarella, E. T., \& Nora, A. (1996). Firstgeneration college students: Characteristics, experiences, and cognitive development. Research in Higher Education, 37(1), 1-22.

Saenz, V. B., Hurtado, S., Barrera, D., Wolf, D., \& Yeung, F. (2007). Los Angeles. CA: Higher Education Research Institute.

(C) The Author 2020. Published by the Coalition of Urban and Metropolitan Universities. www.cumuonline.org Metropolitan Universities | DOI 10.18060/23360 | February 21, 2020 
Seay, S. E., Lifton, E. E., Wuensch, K. L., Bradshaw, L. K., \& McDowelle, J. O. (2008). Firstgeneration graduate students and attrition risks. The Journal of Continuing Higher Education, 56(3), 11-25.

Silvestri, L. \& Oescher, J. (2006). Using rubrics to increase the reliability of assessment in health classes International Electronic Journal of Health Education, 9, 25-30.

Strayhorn, T. L. (2008). How college students’ engagement affects personal and social learning outcomes. Journal of College and Character, 10(2), 1-16.

Stebleton, M. \& Soria, K. (2013). Breaking down barriers: Academic obstacles of firstgeneration students at research universities.

Stebleton, M. J., Soria, K. M., \& Huesman, R. L. (2011). First-generation students' sense of belonging, mental health, and use of counseling services at public research universities. Journal of College Counseling, 17, 6-20.

Stephens, N. M., Fryberg, S. A., Markus, H. R., Johnson, C. S., \& Covarrubias, R. (2012). Unseen disadvantage: American universities' focus on independence undermines the academic performance of first-generation college students. Journal of Personality and Social Psychology, 102(6), 1178-1197.

Tym, C., McMillion, R., Barone, S., \& Webster, J. (2004). First-generation college students: A literature review. Texas Guaranteed Student Loan Corporation. Retrieved from http://search.ebscohost.com.ezproxy.fiu.edu/login.aspx?direct=true\&db=eric\&AN=ED54 2505\&site=eds-live

Warburton, E. C., Bugarin, R., \& Nunez, A. M. (2001). Bridging the Gap: Academic Preparation and Postsecondary Success of First-Generation Students. Statistical Analysis Report. Postsecondary Education Descriptive Analysis Reports.

Whitley, S. E., Benson, G., \& Wesaw, A. (2018). First-generation student success: A landscape analysis of programs and services at four-year institutions. NASPA - Student Affairs Administrators in Higher Education. Retrieved from https://firstgen.naspa.org/2018landscape-analysis\#fullreport

Wilson, E. V. (2004). A standards framework for academic e-advising services. International Journal of Services and Standards, 1(1), 69-82.

Yin, R. K. (1994). Case study research: Design and methods (2nd ed.). Thousand Oaks, CA: Sage. 